\title{
Subclinical hypoperfusion in trauma patients and its influence on surgical fracture fixation: Systematic review and meta-analysis
}

Dr B Grey MBChB, HDip Orth(SA), FCOrth(SA), MMed(Orth)

Orthopaedic Surgeon, Edendale Hospital, Pietermaritzburg and Department of Orthopaedics,

Nelson R Mandela School of Medicine, University of KwaZulu-Natal

Dr G Oosthuizen MBChB, FCS(SA)

Clinical Head: Pietermaritzburg Metropolitan Trauma Service, Department of Surgery,

Nelson R Mandela School of Medicine, University of KwaZulu-Natal, South Africa

Dr R Rodseth MBChB, FCA, MMed, MSc, PhD

Head Clinical Unit: Anaesthesia, Grey's Hospital and Perioperative Research Group, Pietermaritzburg, University of KwaZulu-Natal and Department of OUTCOMES RESEARCH, Cleveland Clinic, Cleveland, Ohio

\author{
Corresponding author: \\ Dr B Grey \\ Department of Orthopaedic Surgery \\ Grey's Hospital \\ Private Bag X9001 \\ Pietermaritzburg, South Africa, 3201 \\ Tel: +27338973299 \\ Email: bcgrey@gmail.com
}

\begin{abstract}
Introduction

Subclinical hypoperfusion (SCH) is present when cellular hypoxia persists in the presence of normal vital signs. Its presence, as well as duration, is associated with poor patient outcomes. Different terminology and various definitions exist for $\mathrm{SCH}$.
\end{abstract}

\section{Methods}

A systematic review was performed on the terminology and definitions used for SCH. Meta-analysis was performed on patients presenting with SCH. Primary study outcomes were mortality, ICU length of stay, and hospital length of stay. When surgical fracture fixation was performed, we compared the incidence of postoperative ventilation, respiratory complications and infective complications in $\mathrm{SCH}$ patients to patients without $\mathrm{SCH}$.

\section{Results}

Eight observational studies were eligible for systematic review and meta-analysis. SCH is more commonly known as occult hypoperfusion, and lactate $\geq 2.5 \mathrm{mmol} / \mathrm{L}$ has been used most commonly to define hypoperfusion. Patients presenting with $\mathrm{SCH}$ had an increased mortality risk ratio of 4.02 (CI 2.62, 6.16). There was a non-significant increase in the standard mean difference for hospital length of stay for patients with SCH $(1.21$ days, 95\% CI [-0.22, 2.64]). When haemodynamically stable trauma patients underwent surgical fracture fixation prior to correction of $\mathrm{SCH}$ they were at increased risk for post-operative ventilation (RR 2.54, 95\% CI [1.56, 4.12]) as well as respiratory (OR 3.88, 95\% CI $[1.38,10.89])$ and infective complications (OR 5.54, 95\% CI [2.02, 15.15]).

\section{Conclusions}

Trauma patients appearing haemodynamically stable should be screened for $\mathrm{SCH}$, especially when early surgical fracture fixation is required.

Key words: subclinical hypoperfusion, occult, lactate, meta-analysis 


\section{Background}

The resuscitation of hypotensive trauma patients has traditionally been based on clinical markers such as heart rate and blood pressure. For the majority of patients this strategy is highly effective; however, recent studies have suggested that a subset of patients will present with normal heart rate and blood pressure while still having a substantially elevated lactate, indicative of cellular hypoxia. ${ }^{1}$ This phenomenon has been termed subclinical or occult hypoperfusion (SCH) and its presence, as well as duration, is correlated with poor patient outcomes. ${ }^{2-5}$ Recent publications have suggested that patients with subclinical hypoperfusion, who undergo surgery in this state, experience worse outcomes. ${ }^{6,7}$

In this study we aimed to: 1) investigate the terminology and definitions used for $\mathrm{SCH} ; 2$ ) undertake a systematic review and meta-analysis to determine the impact of $\mathrm{SCH}$ in haemodynamically stable trauma or polytrauma patients on the outcomes of mortality, intensive care unit (ICU) stay, and hospital stay; and 3) determine whether patients with $\mathrm{SCH}$, who undergo surgical fracture fixation, experience a higher rate of serious intra- and postoperative complications.

\section{Appendix 1. \\ Search strategy and databases}

Database searches were conducted on 5 May 2013 using the OvidSP search engine (Ovid Technologies, Inc., New York, NY 2009) for the following databases:

1. EMBASE 1980 to 2013 Week 18

2. OVID Health Star (1966 to March 2013)

3. Ovid MEDLINE(R) In-Process \& Other Non-Indexed Citations and OVID MEDLINE(R) 1946 to May 5 2013

4. Cochrane Central Register of Controlled Trials (May 12013)

5. Cochrane Database of Systematic Reviews (May 1 2013)

6. ProQuest Dissertations and Theses A\&I (May 12013 )

Example of search conducted in OVID

\begin{tabular}{|l|l|r|}
\hline \multicolumn{2}{|l|}{ Search terms } & 78 \\
\hline 1. & occult hypoperfusion.mp. & 78 \\
\hline 2. & occult hypoperfusion.mp. & 4 \\
\hline 3. & subclinical hypoperfusion.mp. & 2 \\
\hline 4. & subclinical shock.mp. & 34 \\
\hline 5. & occult shock.mp. & 16 \\
\hline 6. & cellular shock.mp. & 15 \\
\hline 7. & cellular dysoxia.mp. & 148 \\
\hline 8. & 2 or 3 or 4 or 5 or 6 or 7 & 70 \\
\hline 9. & remove duplicates from 8 & \\
\hline
\end{tabular}

\section{Methods}

First, to identify the terminology and definitions used for $\mathrm{SCH}$, we conducted a systematic review, identified all studies dealing with this concept, and presented the results in a narrative fashion. Second, to determine the impact of $\mathrm{SCH}$ in haemodynamically stable trauma or polytrauma patients, we extracted those studies that identified patients with $\mathrm{SCH}$ within a population of haemodynamically stable trauma patients. Using data from these studies we then conducted meta-analyses to examine the impact of $\mathrm{SCH}$ on the outcomes of mortality, ICU length of stay, and hospital length of stay. Third, to determine the impact of $\mathrm{SCH}$ on patients who subsequently underwent surgical fracture fixation, we compared the incidence of ventilatory requirement, respiratory complications, and infective complications in SCH patients who underwent surgery to those patients without $\mathrm{SCH}$ who underwent surgery.

\section{Study eligibility}

For this analysis we included all papers regardless of language, study design, sample size, publication status or date of publication. Studies were excluded if they were non-clinical or if they included septic patients. For inclusion, studies had to define haemodynamic stability using both blood pressure and heart rate.

\section{Study identification}

On 5 May 2013 we searched six databases (EMBASE, OVID Health Star, Ovid Medline, Cochrane Central Register of Controlled Trials, Cochrane Database of Systematic Reviews, ProQuest Dissertations and Theses A\&I), consulted with experts, reviewed reference lists from identified articles, and searched for cited references of key publications in Web of Science. The search terms and databases used are listed in Appendix 1. No language filters were used.

\section{Eligibility assessment}

The title and abstract of each citation was independently screened by both BG and RR to identify potentially eligible studies. If either reviewer felt the citation might contain a relevant study, the article was retrieved to undergo full text evaluation. Full texts of all citations identified as being potentially relevant were then independently evaluated by both BG and RR to determine eligibility. Disagreements were solved by consensus. Chance corrected interobserver agreement for study eligibility was tested using kappa statistics. 


\begin{tabular}{|c|c|c|c|}
\hline Study & Terminology & Definition of haemodynamic stability & Method of SCH diagnosis \\
\hline Blow, $1999^{2}$ & Occult hypoperfusion & $\begin{array}{l}\mathrm{SBP}>100 \mathrm{mmHg}, \text { Heart rate }<120 \mathrm{bpm}, \\
\text { Urine output }>1 \mathrm{ml} / \mathrm{kg} / \mathrm{h}\end{array}$ & $\mathrm{LA}>2.5 \mathrm{mmol} / \mathrm{L}$ \\
\hline Claridge, $2000^{3}$ & Occult hypoperfusion & $\begin{array}{l}\mathrm{SBP}>100 \mathrm{mmHg}, \text { Heart rate }<120 \mathrm{bpm}, \\
\text { Urine output }>1 \mathrm{ml} / \mathrm{kg} / \mathrm{h}\end{array}$ & $\mathrm{LA} \geq 2.5 \mathrm{mmol} / \mathrm{L}$ \\
\hline Crowl, $2000^{6}$ & Occult hypoperfusion & $\begin{array}{l}\mathrm{SBP}>100 \mathrm{mmHg} \text {, Heart rate }<120 \mathrm{bpm}, \\
\text { Urine output }>1 \mathrm{ml} / \mathrm{kg} / \mathrm{h}\end{array}$ & $\mathrm{LA} \geq 2.5 \mathrm{mmol} / \mathrm{L}$ \\
\hline Schulman, $2004^{27}$ & Occult hypoperfusion & $\mathrm{N} / \mathrm{A}$ & $\mathrm{LA} \geq 2.5 \mathrm{mmol} / \mathrm{L}$ \\
\hline Ikossi, $2006^{35}$ & $\begin{array}{l}\text { Occult shock, } \\
\text { Occult under-resuscitation }\end{array}$ & $\mathrm{MAP} \geq 70 \mathrm{mmHg}$, Heart rate $\leq 110 \mathrm{bpm}$ & $\mathrm{PmO}_{2} \leq 25$ for at least 2 hours \\
\hline Jansen, $2008^{13}$ & Occult shock & $\mathrm{SBP} \geq 100 \mathrm{mmHg}$ & $\mathrm{LA} \geq 3.5 \mathrm{mmol} / \mathrm{L}$ \\
\hline Callaway, $2009^{12}$ & Occult hypoperfusion & $\mathrm{SBP} \geq 90 \mathrm{mmHg}$ & $\begin{array}{l}\mathrm{LA} \geq 2.5 \mathrm{mmol} / \mathrm{L} \text { or } \\
\mathrm{BD}>0 \mathrm{mEq} / \mathrm{L}\end{array}$ \\
\hline Martin, $2010^{4}$ & Occult hypoperfusion & $\mathrm{SBP} \geq 90 \mathrm{mmHg}$, Heart rate $<120 \mathrm{bpm}$ & $\begin{array}{l}\mathrm{LA}>2.2 \mathrm{mmol} / \mathrm{L} \text { or } \\
\mathrm{BD}<-2 \mathrm{mEq} / \mathrm{L}\end{array}$ \\
\hline Thom, $2010^{15}$ & Occult hypoperfusion & $\begin{array}{l}\mathrm{SBP} \geq 100 \mathrm{mmHg}, \text { Heart rate } \leq 110 \mathrm{bpm}, \\
\text { Temperature }>35^{\circ} \mathrm{C}\end{array}$ & $\begin{array}{l}\mathrm{CI}<2.6 \mathrm{~L} / \mathrm{minute} / \mathrm{m}^{2} \text { or } \\
\mathrm{BE} \leq 3 \mathrm{mEq} / \mathrm{L} \text { or } \mathrm{SI} \geq 0.9 \text { or } \\
\mathrm{ROPE} \geq 3.0\end{array}$ \\
\hline Corradi, $2011^{16}$ & Occult haemorrhagic shock & $\begin{array}{l}\mathrm{SBP} \geq 90 \mathrm{mmHg} \text {, Urine output } \geq 30 \mathrm{ml} / \mathrm{h} \\
\mathrm{LA} \leq 2 \mathrm{mmol} / \mathrm{L} \\
\text { No vasoactive drug support }\end{array}$ & $\begin{array}{l}\text { SCH not identified } \\
\text { Renal doppler RI used to predict } \\
\text { haemorrhagic shock }\end{array}$ \\
\hline Corradi, $2012^{17}$ & Occult haemorrhagic shock & $\mathrm{SBP} \geq 90 \mathrm{mmHg}$, No vasoactive drug support & $\begin{array}{l}\text { SCH not identified } \\
\text { Splenic doppler RI used to } \\
\text { predict haemorrhagic shock }\end{array}$ \\
\hline Grey, $2013^{7}$ & Subclinical hypoperfusion & $\mathrm{MAP} \geq 60 \mathrm{mmHg}$, Heart rate $<110 \mathrm{bpm}$ & $\mathrm{LA} \geq 2.5 \mathrm{mmol} / \mathrm{L}$ \\
\hline Salottolo, $2013^{5}$ & Occult hypoperfusion & $\mathrm{SBP} \geq 90 \mathrm{mmHg}$, Heart rate $<120 \mathrm{bpm}$ & Venous LA $\geq 2.5 \mathrm{mmol} / \mathrm{L}$ \\
\hline Zakrison, $2013^{14}$ & Occult shock & $\mathrm{SBP}>100 \mathrm{mmHg}$, Heart rate $<110 \mathrm{bpm}$ & $\mathrm{BD} \geq 4 \mathrm{mmol} / \mathrm{L}$ \\
\hline
\end{tabular}

\section{Data collection and assessment of study quality}

Data was extracted to an Excel spreadsheet recording: principle author, study design, total number of study patients, number of patients with $\mathrm{SCH}$, number of patients without $\mathrm{SCH}$, mortality, ICU length of stay, hospital length of stay, respiratory complications and infective complications. Authors were contacted to provide original patient data when it was insufficient for meta-analysis. Study quality was evaluated using the Newcastle Ottowa Scale. ${ }^{8}$

\section{Statistical analysis}

Meta-analysis was conducted using a random effects model in Review Manager Version 5.1. (Copenhagen: The Nordic Cochrane Centre, The Cochrane Collaboration, 2011). Heterogeneity was assessed using $\mathrm{I}^{2}$ and chi-squared analysis. Pooled dichotomous outcomes were reported as risk ratios (RR), odds ratios (OR) and 95\% confidence intervals (CI). Continuous outcomes were reported as standard mean difference and 95\% CI. We constructed a funnel plot to assess the possibility of publication bias.

\section{Results}

After having reviewed the results from our systematic review, in addition to articles identified in study reference and by experts, we present a narrative review of the terminology and definitions used for $\mathrm{SCH}$.

When cellular hypoperfusion is present in patients with normal vital signs, a state of $\mathrm{SCH}$ exists. $\mathrm{SCH}$ has previously been referred to as occult hypoperfusion or occult shock and when caused by severe sepsis is commonly known as cryptic shock. ${ }^{9}$ However, we believe $\mathrm{SCH}$ is a more appropriate term for this pathophysiological process as the hypoperfusion is not occult, but rather subclinical, and can easily be detected by the presence of raised lactate or base deficit. $\mathrm{SCH}$ has been well described in elderly trauma patients. This is due in part to the presence of medical comorbidities and the concurrent use of medications such as $\beta$-blockers that may mask the conventional signs of shock in these populations. ${ }^{1,4,5,10-12}$ It has also been described in younger trauma patients when vital signs have been restored back to normal, but where persistent cellular hypoperfusion and oxygen debt remain. ${ }^{1}$ 


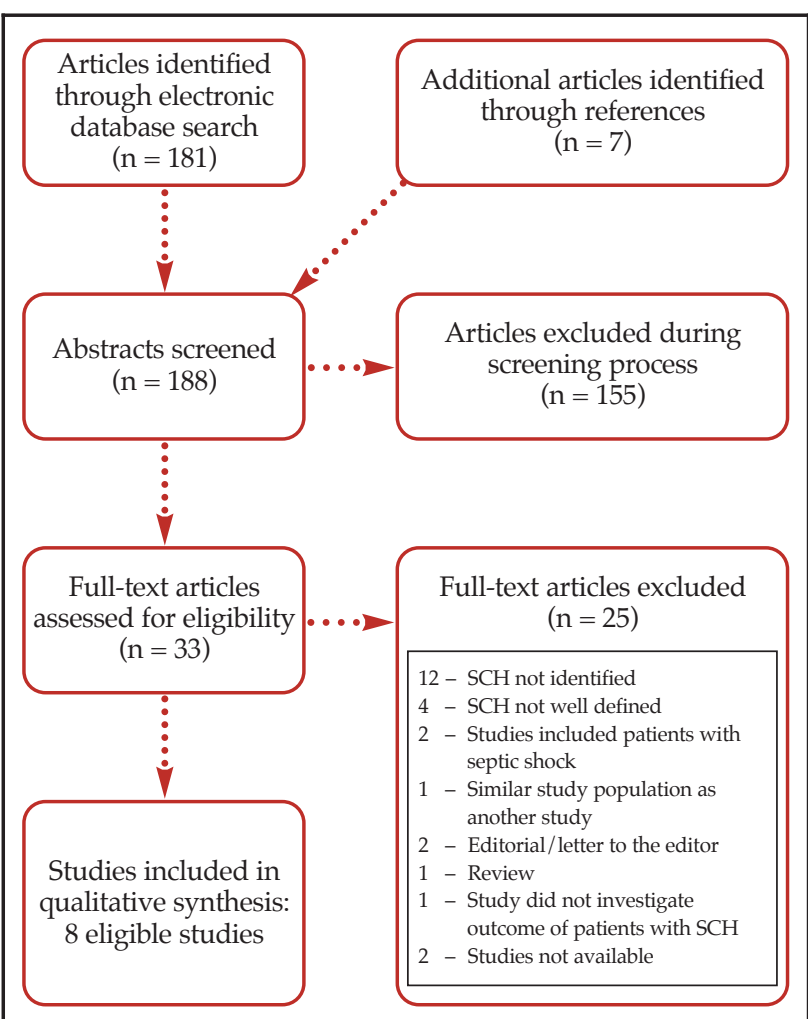

Figure 1. Study selection process

SCH = subclinical hypoperfusion

Various definitions and modalities have been used to define both haemodynamic stability and SCH (Table I). Haemodynamic stability definitions have generally included both systolic blood pressure (SBP) as well as heart rate while some have included mean blood pressure (MAP) and urine output in the definition. For the most part cellular hypoperfusion has been defined as a lactate $\geq 2.5 \mathrm{mmol} / \mathrm{L}$ but some studies have used a higher lactate threshold,$^{13}$ base deficit, ${ }^{4,12,14}$ markers of impaired cardiac output $^{15}$ or organ hypoperfusion..$^{16,17}$
To address our second objective we reviewed the 188 articles that met our search criteria (181 identified through the electronic database search; seven articles identified in references) and identified 33 articles for full text review. The chance corrected inter-observer agreement was excellent (kappa $=0.78$ ). Of these 33 articles, 25 were excluded after full text review as: $\mathrm{SCH}$ was not identified in 12 studies; $;^{10,16-26}$ ) four did not include vital signs or pulse rate in their definition of haemodynamic stability; ${ }^{11-1,27}$ two included patients with sepsis, ${ }^{28,29}$ the patient population in one study was similar to another study; ${ }^{5,30}$ one study did not investigate the outcome of patients with $\mathrm{SCH}_{i}^{.14}$ two citations were editorials or letters to the editor; ${ }^{31,32}$ and one citation was a review article. ${ }^{1}$ We were unable to obtain two articles as they did not provide correspondence details. ${ }^{33,34}$

In SCH, the hypoperfusion is subclinical, and can easily be detected by the presence of raised lactate or base deficit

Eight studies were therefore eligible for meta-analysis (Figure 1). These were all observational studies and their study quality and population characteristics are summarised in Tables II and III.

Seven of the eight studies included in the meta-analysis reported mortality, providing a total of 678 patients with SCH (Figure 2, supplementary data). Patients presenting with $\mathrm{SCH}$ had an increased mortality risk ratio of 4.02 (CI 2.62, 6.16). The pooled results were homogenous $\left(\mathrm{I}^{2}=0 \%\right)$ and no publication bias was evident on the funnel plot (Figure 3, supplementary data).

Only four of the studies provided data for hospital length of stay (Figure 4, supplementary data). There was a non-significant increase in the standard mean difference for hospital length of stay for patients with $\mathrm{SCH}$ (1.21 days, $95 \%$ CI $[-0.22,2.64])$ and this result showed considerable heterogeneity $\left(\mathrm{I}^{2}=99 \%\right)$. Insufficient data were available to analyse ICU length of stay as it was only reported on by two articles. ${ }^{3,4}$

Table II. Nerwcastle-Ottawa Scale assessment of study quality

\begin{tabular}{|c|c|c|c|c|}
\hline Study & Study design & $\begin{array}{l}\text { Selection of study group } \\
\quad \text { (maximum }=4 \text { stars) }\end{array}$ & $\begin{array}{l}\text { Comparability of groups } \\
\text { (maximum }=2 \text { stars) }\end{array}$ & $\begin{array}{l}\text { Ascertainment of outcome } \\
\text { (maximum = } 3 \text { stars) }\end{array}$ \\
\hline Blow $^{2}$ & Retrospective cohort & $\star \star \star \star \star$ & $\star \star$ & $\star \star \star$ \\
\hline Claridge $^{3}$ & Prospective cohort & $\star \star \star \star$ & $\star$ & $\star \star \star$ \\
\hline Crowl $^{6}$ & Retrospective cohort & $\star \star \star$ & $\star \star$ & $\star \star \star$ \\
\hline Ikossi $^{35}$ & Prospective cohort & $\star \star \star \star \star$ & Nil & $\star \star \star$ \\
\hline Martin $^{4}$ & Retrospective cohort & $\star \star$ & $\star$ & $\star \star \star$ \\
\hline Thom $^{15}$ & Prospective cohort & $\star \star \star \star \star$ & $\star$ & $\star \star \star$ \\
\hline Grey $^{7}$ & Retrospective cohort & $\star \star \star$ & $\star \star$ & $\star \star \star$ \\
\hline Salottolo $^{5}$ & Retrospective cohort & $\star \star$ & $\star \star$ & $\star \star \star$ \\
\hline
\end{tabular}


Table III. Study characteristics

\begin{tabular}{|c|c|c|c|c|c|c|c|c|c|}
\hline \multirow{2}{*}{ Study } & \multirow{2}{*}{ Population } & \multicolumn{3}{|c|}{$\begin{array}{l}\text { Total population of stable patients } \\
\text { (mean, SD) }\end{array}$} & \multicolumn{3}{|c|}{$\begin{array}{l}\text { SCH patients } \\
\text { (mean, SD) }\end{array}$} & \multicolumn{2}{|c|}{$\begin{array}{l}\text { No SCH } \\
\text { (mean, SD) }\end{array}$} \\
\hline & & Size (n) & Age & ISS & Size $(\mathrm{n}, \%)$ & Age & ISS & Age & ISS \\
\hline Blow, $1999^{2}$ & $\begin{array}{l}\text { Polytrauma patients: } \\
\text { ISS } \geq 20\end{array}$ & 79 & $\begin{array}{c}43 \\
(19)\end{array}$ & $\begin{array}{c}28 \\
(6.4)\end{array}$ & $\begin{array}{c}58 \\
(73.4)\end{array}$ & $\begin{array}{c}44.7 \\
(19.9)\end{array}$ & $\begin{array}{l}29.2 \\
(6.1)\end{array}$ & $\begin{array}{c}42 \\
(14.6)\end{array}$ & $\begin{array}{c}26 \\
(4.2)\end{array}$ \\
\hline Claridge, $2000^{3}$ & $\begin{array}{l}\text { Trauma patients admitted } \\
\text { to ICU }\end{array}$ & 364 & $\begin{array}{l}43.7 \\
(2.0)\end{array}$ & $\begin{array}{l}23.8 \\
(1.1)\end{array}$ & $\begin{array}{c}246 \\
(67.6)\end{array}$ & $\begin{array}{l}43.2 \\
(2.1)\end{array}$ & $\begin{array}{l}24.9 \\
(1.2)\end{array}$ & $\begin{array}{l}45.1 \\
(1.9)\end{array}$ & $\begin{array}{c}20.3 \\
(1)\end{array}$ \\
\hline Crowl, $2000^{6}$ & $\begin{array}{l}\text { Trauma patients with femur } \\
\text { fractures fixed }<24 \text { hours }\end{array}$ & 47 & $\mathrm{~N} / \mathrm{A}$ & $\begin{array}{r}19.21 \\
(8.2)\end{array}$ & $\begin{array}{c}20 \\
(42.6)\end{array}$ & $\mathrm{N} / \mathrm{A}$ & $\begin{array}{c}21 \\
(10.66)\end{array}$ & $\mathrm{N} / \mathrm{A}$ & $\begin{array}{l}17.42 \\
(6.34)\end{array}$ \\
\hline Ikossi, $2006^{35}$ & $\begin{array}{l}\text { Trauma patients admitted } \\
\text { to ICU, AIS } \geq 3 \text { in any body } \\
\text { region }\end{array}$ & 14 & $\begin{array}{c}40 \\
(18)\end{array}$ & $\mathrm{N} / \mathrm{A}$ & $\begin{array}{c}4 \\
(28.6)\end{array}$ & $\mathrm{N} / \mathrm{A}$ & N/A & $\mathrm{N} / \mathrm{A}$ & $\begin{array}{c}29 \\
(10)\end{array}$ \\
\hline Martin, $2010^{4}$ & $\begin{array}{l}\text { Geriatric trauma patients }>65 \\
\text { years }\end{array}$ & 72 & $\mathrm{~N} / \mathrm{A}$ & 8.18 & $\begin{array}{c}28 \\
(38.9)\end{array}$ & $\mathrm{N} / \mathrm{A}$ & 10.5 & $\mathrm{~N} / \mathrm{A}$ & 6.7 \\
\hline Thom, $2010^{15}$ & $\begin{array}{l}\text { Polytrauma patients: } \\
\text { ISS }>15 \text { or significant injury } \\
\text { to } \geq \text { two body regions }\end{array}$ & 62 & $\begin{array}{c}52 \\
(21)\end{array}$ & $\begin{array}{c}19 \\
(11)\end{array}$ & $\begin{array}{c}7 \\
(11.3)\end{array}$ & $\begin{array}{c}58 \\
(20)\end{array}$ & $\begin{array}{l}29 \\
(9)\end{array}$ & $\begin{array}{l}49 \\
(21)\end{array}$ & $\begin{array}{c}17.7 \\
(11.3)\end{array}$ \\
\hline Grey, $2013^{7}$ & $\begin{array}{l}\text { Polytrauma patients: } \\
\text { NISS > } 16\end{array}$ & 36 & $\begin{array}{c}35.8 \\
(14.9)\end{array}$ & $\begin{array}{c}24.67 \\
(10.871)\end{array}$ & $\begin{array}{c}19 \\
(52.8)\end{array}$ & $\begin{array}{c}37.3 \\
(15.37)\end{array}$ & $\begin{array}{c}32.1 \\
(8.42)^{*}\end{array}$ & $\begin{array}{c}34.2 \\
(14.37)\end{array}$ & $\begin{array}{c}28 \\
(9.55)^{*}\end{array}$ \\
\hline Salottolo, $2013^{5}$ & $\begin{array}{l}\text { Geriatric trauma patients } \\
\geq 65 \text { years }\end{array}$ & 1416 & 79 & 9 & $\begin{array}{c}300 \\
(21.2)\end{array}$ & $\mathrm{N} / \mathrm{A}$ & $\mathrm{N} / \mathrm{A}$ & $\mathrm{N} / \mathrm{A}$ & $\mathrm{N} / \mathrm{A}$ \\
\hline
\end{tabular}

For our third objective we identified only two studies that investigated outcomes in patients undergoing surgical fracture fixation in the presence of $\mathrm{SCH}^{6,7}$ Crowl et al. reported on the incidence of post-operative complications among patients with $\mathrm{SCH}$ undergoing intramedullary nailing of femur fractures in the first 24 hours post admission. ${ }^{6}$ Different systemic complications were noted, including respiratory, cardiac, haematologic, neurologic, gastrointestinal, musculoskeletal and infectious. Patients with $\mathrm{SCH}$ had significantly more post-operative complications. Thirty-five complications were encountered in the 20 patients with $\mathrm{SCH}$, compared with 11 complications in the control group of 27 patients. Ventilation requirement was also reported. Thirteen patients with $\mathrm{SCH}$ required ventilation, compared with only five patients from the control group.

The study by Grey et al. reported on the outcome of polytrauma patients with $\mathrm{SCH}$ undergoing early surgical fracture stabilisation. ${ }^{7}$ Their primary findings were higher inotrope requirements in the first 24 hours post-operatively $(p=0.02)$ and higher sequential organ failure assessment (SOFA) scores on day three $(\mathrm{p}=0.003)$ in the $\mathrm{SCH}$ group. For the purposes of this meta-analysis the original data from Grey's study were used to investigate the outcomes of ventilation requirement, respiratory complications and infective complications.
When haemodynamically stable trauma patients underwent surgical fracture fixation prior to correction of $\mathrm{SCH}$ they had an increased likelihood for ventilation postoperatively (RR 2.54, 95\% CI [1.56, 4.12]) and a higher incidence of respiratory (OR 3.88, 95\% CI [1.38, 10.89]) and infective complications (OR 5.54, 95\% CI [2.02, 15.15]) (Figures 5-7, supplementary data).

\section{Discussion}

\section{Statement of principle findings}

First, our systematic review of the literature identified a wide range of definitions for $\mathrm{SCH}$, the majority of which included a lactate measurement $\geq 2.5 \mathrm{mmol} / \mathrm{L}$ in the presence of normal haemodynamic parameters (Table I). Secondly, meta-analysis found patients with $\mathrm{SCH}$ were at increased risk of mortality (RR 4.02; 95\% CI 2.62-6.16; $\mathrm{I}^{2}=0 \%$ ) and showed a non-significant increase in hospital length of stay (mean difference 1.21 days; 95\% CI $-0.22-2.64 ; \mathrm{I}^{2}=99 \%$ ). Finally, patients with SCH who underwent surgical fracture fixation within the first 24 hours of presentation required more ventilation (RR 2.54, 95\% CI 1.56-4.12; $\mathrm{I}^{2}=0 \%$ ), and were at a higher risk of respiratory (OR 3.88, 95\% CI 1.38-10.89; $\mathrm{I}^{2}=0 \%$ ) and infective complications $\left(5.54,95 \%\right.$ CI $\left.2.02-15.15, \mathrm{I}^{2}=0 \%\right)$. 


\begin{tabular}{|c|c|c|c|c|c|c|c|c|c|c|}
\hline \multirow[b]{2}{*}{ Study or Subgroup } & \multicolumn{2}{|l|}{ SCH } & \multicolumn{2}{|c|}{ No SCH } & \multirow[b]{2}{*}{ Weight } & \multirow{2}{*}{$\begin{array}{c}\text { Risk Ratio } \\
\text { M-H, Fixed, } 95 \% \mathrm{Cl}\end{array}$} & \multirow{2}{*}{\multicolumn{4}{|c|}{$\begin{array}{c}\text { Risk Ratio } \\
\text { M-H, Fixed, 95\% Cl }\end{array}$}} \\
\hline & Events & Total & Events & Total & & & & & & \\
\hline Blow, 1999 & 8 & 58 & 0 & 21 & $3.8 \%$ & $6.34[0.38,105.27]$ & & & & \\
\hline Claridge, 2000 & 11 & 246 & 1 & 118 & $7.1 \%$ & $5.28[0.69,40.39]$ & & & & \\
\hline Crowl, 2000 & 0 & 20 & 0 & 27 & & Not estimable & & & & \\
\hline Grey, 2013 & 1 & 19 & 0 & 17 & $2.8 \%$ & $2.70[0.12,62.17]$ & & & & \\
\hline Ikossi, 2006 & 0 & 0 & 0 & 0 & & Not estimable & & & & \\
\hline Martin, 2010 & 7 & 28 & 3 & 44 & $12.2 \%$ & $3.67[1.03,13.01]$ & & & & \\
\hline Salattolo, 2013 & 32 & 300 & 33 & 1116 & $73.4 \%$ & $3.61[2.26,5.77]$ & & & & \\
\hline Thom, 2010 & 2 & 7 & 0 & 55 & $0.7 \%$ & $35.00[1.84,665.11]$ & & & & $\longrightarrow$ \\
\hline Total $(95 \% \mathrm{Cl})$ & & 678 & & 1398 & $100.0 \%$ & $4.02[2.62,6.16]$ & & & & \\
\hline Total events & 61 & & 37 & & & & & & & \\
\hline $\begin{array}{l}\text { Heterogeneity: } \mathrm{Chi}^{2}= \\
\text { Test for overall effect }\end{array}$ & $\begin{array}{l}2.53, d f= \\
Z=6.38\end{array}$ & $\begin{array}{l}5(P= \\
P<0.0\end{array}$ & $\begin{array}{l}0.77) ; 1^{2}= \\
00001)\end{array}$ & $=0 \%$ & & & 0.01 & ${ }_{\text {No } \mathrm{SCH}^{1}}^{1}$ & $\mathrm{sch}{ }^{10}$ & 100 \\
\hline
\end{tabular}

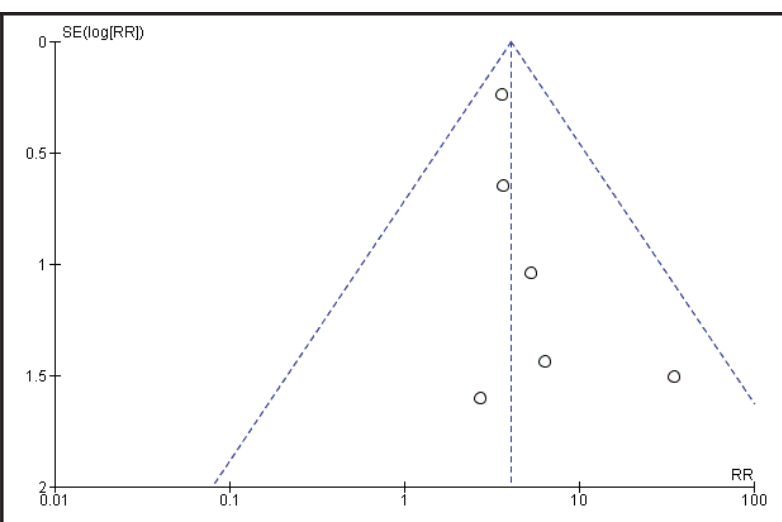

Figure 3. Funnel plot showing distribution of treatment effect of studies investigating mortality in patients presenting with $\mathrm{SCH}$

These studies were all of good quality as measured by the Newcastle-Ottowa Scale
Strengths and weakness of this review

There were several limitations to this meta-analysis. There has been very little published on $\mathrm{SCH}$ and the eight studies included in the meta-analysis were all observational studies. However, these studies were all of good quality as measured by the Newcastle-Ottowa Scale (Table II). The study populations in the eight papers were all trauma patients with variable injury severity and age groups. Three papers investigated $\mathrm{SCH}$ in polytrauma patients $\mathrm{S}^{2,715}$ and different definitions of polytrauma were used; Blow et al. defined polytrauma as ISS > 20; Thom et al. defined polytrauma as ISS $>15$ or significant injury to two or more body regions; and Grey et al. used the New Injury Severity Score (NISS) $>16$ to define polytrauma. Two papers included trauma patients admitted to intensive care units but did not score the injury severity. ${ }^{3,35}$ The study by Crowl et al. investigated trauma patients with femur fractures that were fixed with intramedullary nails within the first 24 hours. ${ }^{6}$ Twelve out of the 20 patients with SCH had ISS $>18$. Two studies focused on $\mathrm{SCH}$ in the elderly ( $>65$ years) trauma population but did not select patients based upon their ISS..$^{4,5}$ Only two studies with small patient numbers were available for the third objective of this meta-analysis to determine the impact of $\mathrm{SCH}$ on trauma patients going for surgical fracture fixation. ${ }^{6,7}$

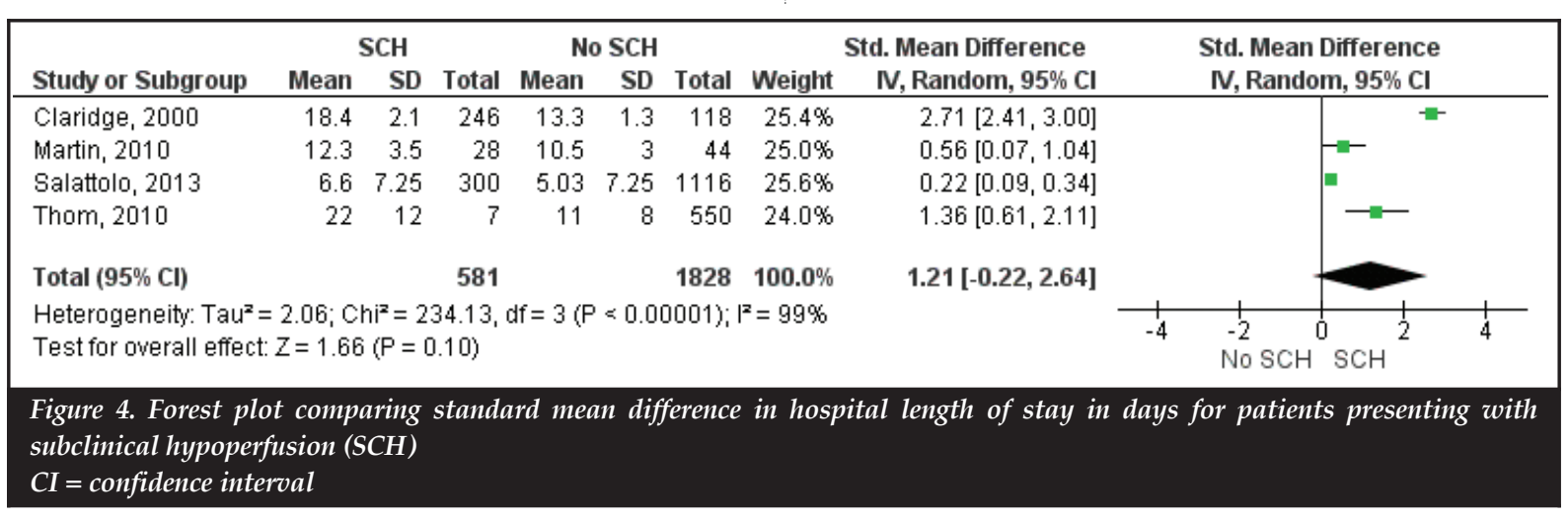




\section{Interpretation and implication of findings}

This analysis highlights a few key points with regard to $\mathrm{SCH}$ in the trauma population. Various definitions have been used to describe haemodynamic stability and SCH (Table I).

Our study emphasises the use of cellular hypoperfusion markers rather than traditional vital signs in the assessment of shock and resuscitation

The target systolic blood pressure and mean arterial pressure in trauma patients is debatable, and is influenced by the patient's age, cardiovascular conditioning and other medical comorbidities. The systolic blood pressures or mean arterial pressures used in the included studies were adequate in selecting clinically apparent haemodynamically stable patients, provided the pulse rate was also normal. To allow for the normal sympathetic response to trauma and pain, the maximum heart rate used to define haemodynamic stability in all the studies was either 110 or 120 beats per minute. Our study emphasises the use of cellular hypoperfusion markers rather than traditional vital signs in the assessment of shock and resuscitation.
The most common marker used to identify $\mathrm{SCH}$ was lactate. Most authors chose a minimum value of $2.5 \mathrm{mmol} / \mathrm{L}$ to define cellular hypoperfusion. In the presence of normal vital signs this was accurate in identifying $\mathrm{SCH}$. More direct ways to detect hypoperfusion have been investigated such as the Licox polarographic tissue oxygen monitor that measures partial pressure of oxygen in deltoid muscle ${ }^{35}$ as well as renal - and splenic Doppler resistive indices. ${ }^{16,17}$ These indices should be investigated further as possible markers for $\mathrm{SCH}$.

This study affirms other studies that show that trauma patients presenting with $\mathrm{SCH}$ have worse outcomes. Even though these patients appeared haemodynamically stable, they still had a four-fold higher mortality than patients without $\mathrm{SCH}$. All trauma patients and especially polytrauma patients need to be screened for $\mathrm{SCH}$ by having lactate or base deficit measured. A recent survey among Canadian traumatologists revealed that even though $78 \%$ of respondents were aware of $\mathrm{SCH}$, only $8 \%$ were screening for $\mathrm{SCH}^{36}$ A further $88 \%$ felt that they should be screening for $\mathrm{SCH}$.

\begin{tabular}{|c|c|c|c|c|c|c|c|c|c|c|}
\hline Study or Subgroup & \multicolumn{2}{|c|}{ SCH } & $\begin{array}{l}\text { No SC } \\
\text { Events }\end{array}$ & No SCH & Weight & $\begin{array}{c}\text { Risk Ratio } \\
\text { M-H, Random, } 95 \% \mathrm{Cl}\end{array}$ & \multicolumn{4}{|c|}{$\begin{array}{c}\text { Risk Ratio } \\
\text { M-H, Random, } 95 \% \mathrm{Cl}\end{array}$} \\
\hline Crowl, 2000 & 13 & 20 & 5 & 27 & $32.2 \%$ & $3.51[1.49,8.25]$ & & & - & \\
\hline Grey, 2013 & 17 & 19 & 7 & 17 & $67.8 \%$ & $2.17[1.21,3.91]$ & & & -1 & \\
\hline Total $(95 \% \mathrm{Cl})$ & & 39 & & 44 & $100.0 \%$ & $2.54[1.56,4.12]$ & & & & \\
\hline Total events & 30 & & 12 & & & & & & & \\
\hline \multicolumn{6}{|c|}{$\begin{array}{l}\text { Heterogeneity: } \text { Tau }^{2}=0.00 ; \mathrm{Chi}^{2}=0.86, \mathrm{df}=1(\mathrm{P}=0.35) ; \mathrm{I}^{2}=0 \% \\
\text { Test for overall effect: } Z=3.76(\mathrm{P}=0.0002)\end{array}$} & & 0.01 & ${ }^{0.1} \mathrm{SCH}^{1}$ & ${ }^{1} \mathrm{scH}$ & 100 \\
\hline
\end{tabular}

\begin{tabular}{|c|c|c|c|c|c|c|c|c|c|c|}
\hline Study or Subgroup & \multicolumn{2}{|l|}{ SCH } & \multicolumn{2}{|c|}{ No SCH } & Weight & $\begin{array}{c}\text { Odds Ratio } \\
\text { M-H, Fixed, 95\% Cl }\end{array}$ & \multicolumn{3}{|c|}{$\begin{array}{c}\text { Odds Ratio } \\
\text { M-H, Fixed, 95\% Cl }\end{array}$} & \\
\hline Crowl, 2000 & 6 & 20 & 4 & 27 & $64.1 \%$ & $2.46[0.59,10.29]$ & & 7 & 70 & \\
\hline Grey, 2013 & 11 & 19 & 3 & 17 & $35.9 \%$ & $6.42[1.37,30.05]$ & & & $=$ & \\
\hline Total $(95 \% \mathrm{Cl})$ & & 39 & & 44 & $100.0 \%$ & $3.88[1.38,10.89]$ & & & & \\
\hline Total events & 17 & & 7 & & & & & & & \\
\hline $\begin{array}{l}\text { Heterogeneity: } \mathrm{Chi}^{2}= \\
\text { Test for overall effect }\end{array}$ & $\begin{array}{l}0.80, d f= \\
Z=2.58(\end{array}$ & $\begin{array}{l}1(P= \\
P=0.0\end{array}$ & $\begin{array}{l}0.37) ; 1^{2}= \\
110)\end{array}$ & $=0 \%$ & & & 0.01 & ${ }^{0.1} \mathrm{SCH}^{1}$ & $\mathrm{SCH}$ & 100 \\
\hline
\end{tabular}

\begin{tabular}{|c|c|c|c|c|c|c|c|c|c|c|}
\hline Study or Subgroup & $\begin{array}{l}\text { SCH } \\
\text { Events }\end{array}$ & Total & $\begin{array}{l}\text { No SCl } \\
\text { Events }\end{array}$ & Total & Weight & $\begin{array}{c}\text { Odds Ratio } \\
\text { M-H, Fixed, } 95 \% \mathrm{Cl}\end{array}$ & \multicolumn{3}{|c|}{$\begin{array}{c}\text { Odds Ratio } \\
\text { M-H, Fixed, } 95 \% \mathrm{Cl}\end{array}$} & \\
\hline Crowl, 2000 & 13 & 20 & 5 & 27 & $44.8 \%$ & $8.17[2.15,31.11]$ & & & च- & \\
\hline Grey, 2013 & 8 & 19 & 3 & 17 & $55.2 \%$ & $3.39[0.72,15.90]$ & & & & \\
\hline Total $(95 \% \mathrm{Cl})$ & & 39 & & 44 & $100.0 \%$ & $5.54[2.02,15.15]$ & & & & \\
\hline Total events & 21 & & 8 & & & & & & & \\
\hline $\begin{array}{l}\text { Heterogeneity: } \mathrm{Chi}^{2} \\
\text { Test for overall effect }\end{array}$ & $\begin{array}{l}0.71, \mathrm{df}= \\
Z=3.33(\end{array}$ & $\begin{array}{l}1(P= \\
P=0.0\end{array}$ & $\begin{array}{l}0.40) ;\left.\right|^{2}= \\
(009)\end{array}$ & $=0 \%$ & & & 0.01 & ${ }^{0.1} \mathrm{SCH}^{1}$ & $\mathrm{sCH}$ & 100 \\
\hline
\end{tabular}


Our study also showed that surgical fracture fixation in the presence of $\mathrm{SCH}$ was associated with increased perioperative morbidity. Even though only two studies with small patient numbers were available for this part of the meta-analysis, both studies were of good quality. Both these studies investigated fracture fixation in the presence of SCH. The timing and the type of fracture fixation in the trauma patient is influenced by the haemodynamic state of the patient. Early definitive fracture fixation, also known as 'early total care', has been advocated in haemodynamically stable polytrauma patients. ${ }^{37-39}$ This has been shown to reduce fat embolism syndrome (FES), acute respiratory distress syndrome (ARDS), pneumonia and ICU length of stay. We advocate delaying early definitive fracture fixation in haemodynamically stable trauma patients with $\mathrm{SCH}$ until resuscitation is complete. While aiming to do early definitive fixation in the first 24 hours, $\mathrm{O}^{\prime}$ Toole et al. safely delayed femoral nailing in polytrauma patients (ISS > 17) until resuscitation was complete as evidenced by a normalising lactate. ${ }^{40}$ Femoral nailing started more than 8 hours after admission to theatre in $48 \%$ of their patients and this approach was associated with an ARDS rate of $1.5 \%$ and a mortality rate of $2 \%$.

\section{Future research}

Very little research has been done into $\mathrm{SCH}$ and no randomised controlled trials have been conducted on the subject. We know that both the presence of $\mathrm{SCH}$ and surgery in the presence of $\mathrm{SCH}$ is detrimental, but prospective randomised controlled trials are required to prove that patients presenting with $\mathrm{SCH}$ have improved outcomes when surgery is delayed until lactate normalises.

\section{Conclusion}

$\mathrm{SCH}$ is most commonly defined as serum lactate $\geq 2.5 \mathrm{mmol} / \mathrm{L}$ in the presence of normal vital signs. The presence of $\mathrm{SCH}$ in clinically stable trauma patients was associated with a four-fold increase in mortality risk as well as a non-significant increase in hospital length of stay. Trauma patients should therefore be screened for $\mathrm{SCH}$. Trauma patients who underwent surgical fracture fixation in the presence of $\mathrm{SCH}$ required more ventilation and were at a higher risk of respiratory and infective complications. When possible, fracture fixation should be delayed until SCH is corrected. Prospective randomised controlled trials are needed to investigate this further.

The content of this article is the original work of the authors. No benefits of any form have been or are to be received from a commercial party related directly or indirectly to the subject of this article.

\section{References}

(underlined references included in meta-analysis)

1. Barbee RW, Reynolds PS, Ward KR. Assessing shock resuscitation strategies by oxygen debt repayment. Shock. [Review]. 2010 February;33(2):113-22.

2. Blow O, Magliore L, Claridge JA, Butler K, Young JS. The golden hour and the silver day: detection and correction of occult hypoperfusion within 24 hours improves \begin{tabular}{lllll}
\hline outcome from major trauma. I Trauma. 1999 \\
\hline
\end{tabular} Nov;47(5):964-69.

3. Claridge JA, Crabtree TD, Pelletier SJ, Butler K, Sawyer RG, Young JS. Persistent occult hypoperfusion is associated with a significant increase in infection rate and mortality in major trauma patients. I Trauma. 2000 Jan;48(1):8-14; discussion -5.

4. Martin JT, Alkhoury F, O'Connor JA, Kyriakides TC, Bonadies JA. 'Normal' vital signs belie occult hypoperfusion in geriatric trauma patients. Am Surg. 2010 Jan;76(1):65-69.

5. Salottolo KM, Mains CW, Offner PJ, Bourg PW, Bar-Or D. A retrospective analysis of geriatric trauma patients: venous lactate is a better predictor of mortality than traditional vital signs. Scand J Trauma Resusc Emerg Med. 2013;21:7.

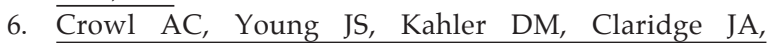
Chrzanowski DS, Pomphrey M. Occult hypoperfusion is associated with increased morbidity in patients undergoing early femur fracture fixation. J Trauma. 2000 Feb;48(2):260-67.

7. Grey B, Rodseth RN, Muckart DJ. Early fracture stabilisation in the presence of subclinical hypoperfusion. Injury. $2013 \mathrm{Feb}$;4(2):217-20.

8. Newcastle-Ottawa Quality Assessment Scale. Ottawa Health Research Institute; [1 January 2014]; http:/ / www.ohri.ca/ programs / clinical_epidemiology/n osgen.doc].

9. Puskarich MA, Trzeciak S, Shapiro NI, Heffner AC, Kline JA, Jones AE. Outcomes of patients undergoing early sepsis resuscitation for cryptic shock compared with overt shock. Resuscitation. 2011 Oct;82(10):1289-93.

10. Scalea TM, Simon HM, Duncan AO, Atweh NA, Sclafani SJ, Phillips TF, Shaftan GW. Geriatric blunt multiple trauma: improved survival with early invasive monitoring. $J$ Trauma. 1990 Feb;30(2):129-34; discussion 34-6.

11. Schulman AM, Claridge JA, Young JS. Young versus old: factors affecting mortality after blunt traumatic injury. Am Surg. 2002 Nov;68(11):942-47; discussion 7-8.

12. Callaway DW, Shapiro NI, Donnino MW, Baker C, Rosen CL. Serum lactate and base deficit as predictors of mortality in normotensive elderly blunt trauma patients. $J$ Trauma. 2009 Apr;66(4):1040-44.

13. Jansen TC, van Bommel J, Mulder PG, Rommes JH, Schieveld SJ, Bakker J. The prognostic value of blood lactate levels relative to that of vital signs in the prehospital setting: a pilot study. Critical care (London, England). 2008;12(6):R160.

14. Zakrison T, McFarlan A, Wu YY, Keshet I, Nathens A. Venous and arterial base deficits: Do these agree in occult shock and in the elderly? A Bland-Altman analysis. Journal of Trauma and Acute Care Surgery. 2013 March;74(3):936-39. 
15. Thom O, Taylor DM, Wolfe RE, Myles P, Krum H, Wolfe R. Pilot study of the prevalence, outcomes and detection of occult hypoperfusion in trauma patients. Emergency Medicine Journal. 2010 June;27(6):470-72.

16. Corradi F, Brusasco C, Vezzani A, Palermo S, Altomonte F, Moscatelli P, Pelosi P. Hemorrhagic shock in polytrauma patients: early detection with renal Doppler resistive index measurements. Radiology. 2011 Jul;260(1):112-18.

17. Corradi F, Brusasco C, Garlaschi A, Santori G, Vezzani A, Moscatelli P, Pelosi P. Splenic Doppler resistive index for early detection of occult hemorrhagic shock after polytrauma in adult patients. Shock. 2012 Nov;38(5):46673.

18. Bradburn E, Rogers FB, Krasne M, Rogers A, Horst MA, Beelen MJ, Miller JA. High-risk geriatric protocol: improving mortality in the elderly. J Trauma Acute Care Surg. 2012 Aug;73(2):435-40.

19. Chytra I, Pradl R, Bosman R, Pelnar P, Kasal E, Zidkova A. Esophageal Doppler-guided fluid management decreases blood lactate levels in multiple-trauma patients: a randomized controlled trial. Crit Care. 2007;11(1):R24.

20. Guyette FX, Gomez H, Suffoletto B, Quintero J, Mesquida J, Kim HK, Hostler D, Puyana JC, Pinsky MR. Prehospital dynamic tissue oxygen saturation response predicts inhospital lifesaving interventions in trauma patients. J Trauma Acute Care Surg. 2012 Apr;72(4):930-35.

21. Rogers A, Rogers F, Bradburn E, Krasne M, Lee J, Wu D, Edavettal M, Horst M. Old and undertriaged: a lethal combination. Am Surg. 2012 Jun;78(6):711-15.

22. Abramson D, Scalea TM, Hitchcock R, Trooskin SZ, Henry SM, Greenspan J. Lactate clearance and survival following injury. J Trauma. 1993 Oct;35(4):584-88; discussion 8-9.

23. Manikis P, Jankowski S, Zhang H, Kahn RJ, Vincent JL. Correlation of serial blood lactate levels to organ failure and mortality after trauma. Am J Emerg Med. 1995 Nov;13(6):619-22.

24. Lipsky AM, Gausche-Hill M, Henneman PL, Loffredo AJ, Eckhardt PB, Cryer HG, de Virgilio C, Klein SL, Bongard FS, Lewis RJ. Prehospital hypotension is a predictor of the need for an emergent, therapeutic operation in trauma patients with normal systolic blood pressure in the emergency department. J Trauma. 2006 Nov;61(5):1228-33.

25. Morshed S, Corrales LA, Lin K, Miclau T. Femoral nailing during serum bicarbonate-defined hypo-perfusion predicts pulmonary organ dysfunction in multi-system trauma patients. Injury. 2011 Jul;42(7):643-49.

26. Guyette F, Suffoletto B, Castillo JL, Quintero J, Callaway C, Puyana JC. Prehospital serum lactate as a predictor of outcomes in trauma patients: a retrospective observational study. J Trauma. 2011 Apr;70(4):782-86.

27. Schulman AM, Claridge JA, Carr G, Diesen DL, Young JS. Predictors of patients who will develop prolonged occult hypoperfusion following blunt trauma. Journal of Trauma Injury, Infection and Critical Care. 2004 October;57(4):795800.

28. Yu M, Morita SY, Daniel SR, Chapital A, Waxman K, Severino R. Transcutaneous pressure of oxygen: a noninvasive and early detector of peripheral shock and outcome. Shock. 2006 Nov;26(5):450-56.
29. Lawniczak RA, Jones-Bamman C, Dugas A, Giberson T, Cocchi MN, Donnino M. 313 Evaluation of the Management and Outcome of Patients With Occult Hypoperfusion in the Emergency Department. Annals of emergency medicine. 2011;58(4):S283.

30. Bar-Or D, Salottolo KM, Orlando A, Mains CW, Bourg P, Offner PJ. Association between a geriatric trauma resuscitation protocol using venous lactate measurements and early trauma surgeon involvement and mortality risk. $J$ Am Geriatr Soc. 2013 Aug;61(8):1358-64.

31. Honore PM, Joannes-Boyau O, Boer W, Collin V. Regional occult hypoperfusion detected by lactate and Sequential Organ Failure Assessment subscores: Old tools for new tricks? Critical Care Medicine. [Editorial]. 2009 August;37(8):2477-78.

32. Kepros JP. Occult hypoperfusion and long-bone fixation. J Trauma. 2002 Jan;52(1):189.

33. Zakrison TL, Soklaridis S, Rizoli S. ‘We Train Our Jewelers Better Than Our Trauma Surgeons' How Global Trauma Surgeons Recognize Occult Shock. The Journal of surgical research. 2013;179(2):344.

34. Rodriguez A, Vetere L, Egurrola A, Hernandez M, Chiacchiara D, Pusajo J. Significance of different levels of gastric intramural $\mathrm{pH}$. [Spanish]

Significacion De Diferentes Niveles De Ph Intramural Gastrico. Medicina Intensiva. 1998 February;22(2):55-59.

35. Ikossi DG, Knudson MM, Morabito DJ, Cohen MJ, Wan JJ, Khaw L, Stewart CJ, Hemphill C, Manley GT. Continuous muscle tissue oxygenation in critically injured patients: A prospective observational study. Journal of Trauma - Injury, Infection and Critical Care. 2006 October;61(4):780-88.

36. Zakrison T, Leung E, McCredie V, Nathens A, Diez C, Rizoli S, Namias N. Canadian traumatologists and the recognition of occult shock: Results of a national survey. Panam J Trauma Critical Care Emerg Surg. 2013;2(1):33-36.

37. Johnson KD, Cadambi A, Seibert GB. Incidence of adult respiratory distress syndrome in patients with multiple musculoskeletal injuries: effect of early operative stabilization of fractures. I Trauma. 1985 May;25(5):375-84.

38. Seibel R, LaDuca J, Hassett JM, Babikian G, Mills B, Border DO, Border JR. Blunt multiple trauma (ISS 36), femur traction, and the pulmonary failure-septic state. Ann Surg. 1985 Sep;202(3):283-95.

39. Bone LB, Johnson KD, Weigelt J, Scheinberg R. Early versus delayed stabilization of femoral fractures. A prospective randomized study. J Bone Joint Surg Am. 1989 Mar;71(3):336-40.

40. O'Toole RV, O'Brien M, Scalea TM, Habashi N, Pollak $\mathrm{AN}$, Turen $\mathrm{CH}$. Resuscitation before stabilization of femoral fractures limits acute respiratory distress syndrome in patients with multiple traumatic injuries despite low use of damage control orthopedics. J Trauma. 2009 Nov;67(5):1013-21.

This article is also available online on the SAOA website (www.saoa.org.za) and the SciELO website (www.scielo.org.za). Follow the directions on the Contents page of this journal to access it. 